\title{
Health Outcomes and Health Spending in the United States and the Nordic Countries
}

\author{
Adnan Kisa \\ Kristiania University College-Norway
}

\begin{abstract}
There is a broad consensus that the Nordic countries spend less on health care but get better health outcomes than the U.S. The study aims to compare health outcomes and health spending and compare the top ten causes and risk factors for disability-adjusted life-years (DALYS) in U.S. and Nordic countries. In both health systems, high body-mass index, high fasting plasma glucose, high blood pressure, and high LDL were found as the leading risk factors contributing to death and disability combined. Ischemic heart disease, Alzheimer's disease, stroke, lung cancer, and COPD are among the top five conditions that cause the most deaths in both health systems. It was found that the Nordic system has lower health costs due to its strong primary care system, more services, universal access to health care without financial barriers, and a generally healthy lifestyle. The study shows that there are many lessons that the U.S. and Nordic countries can learn from each other.
\end{abstract}

Keywords: Nordic health system, US health system, health outcomes, health expenditures

\section{INTRODUCTION}

\section{The Nordic Health System}

The Nordic countries consist of Denmark, Norway, Sweden, Finland, and Iceland. All persons living in the Nordic countries are covered by a compulsory social security system and health insurance scheme (Scheele et al., 2017). According to the principle of free, equally accessible health services, everyone residing in these countries can access the health system and services regardless of their social or economic situation (Knudsen et al., 2019). Financing of the system is usually provided through taxes. In these countries, the state is responsible for the quality of health services, the determination of capacity in all regions, and health policies (Magnussen et al., 2009). Central governments determine their countries' health policies, and municipalities and regional authorities offer many health services, including primary care. The common characteristics of the health systems of these countries are as follows (Magnussen et al., 2009; Scheele et al., 2017; Ringsberg and Borup, 2011):

\section{The U.S. Health System}

The U.S. health care system is defined as a hybrid system, a combination of public health and private insurance. The U.S. does not have universal health insurance coverage, and only recently has the Affordable Care Act (Obamacare) enacted mandating health insurance for nearly everyone (Page, 2016). About 9.2\% of the American people were uninsured in 2019. In 2019, the federal government accounted for $29 \%$ of health spending, households accounted for $28 \%$, followed by $19 \%$ by private businesses, $16 \%$ by state and 
local governments, and 7\% from other private revenue (CMS, 2021).

The characteristics of the U.S. health system are as follows:

- Funding and Types of Health Insurance:

- Veterans Administrations (V.A.): Similar to the U.K. National Health Services (NHS), only for military veterans (1.4\% in 2019) (CMS, 2021; Shi and Singh, 2015),

- Medicare: a health insurance program for people age 65 or older, people under 65 with certain disabilities, and people of all ages with end-stage renal disease $(14.2 \%$ of the U.S. population in 2019) (CMS, 2021; Rowland and Garfield, 2000),

- Medicaid: health coverage for low-income adults, children, pregnant women, elderly adults, and people with disabilities (19.8\% of the U.S. population in 2019) (Rowland and Garfield, 2000; Turner, 2002),

- Private insurance (49.6\% provided by employers, 5.9\% non-group ) (CMS, 2021)

- Out of pocket payments.

- Advanced diagnostic and therapeutic technology (Luft, 2006),

- Timely availability of subspecialists and procedures (Turner, 2002),

- Limited access to multiple underserved populations (Baurer et al., 2014),

- High cost with marginal population outcomes (Rushton, 2009),

- Insufficient primary care workforce (Berwick et al., 2008),

- Highly bureaucratic/administrative costs (Page, 2016).

\section{HEALTH OUTCOMES AND HEALTH SPENDING}

Table 1 provides general demographic, mortality, life expectancy, and health spending information for both the U.S. and the Nordic countries. The U.S. population was about 328 million, and the Nordic countries' population was about 27 million. Iceland had the fewest people, and Sweden had the highest number of people among the Nordic countries in 2019. The GDP per capita was $\$ 53,535$ for the U.S. and $\$ 40,215$ and $\$ 63,501$ for Finland and Norway, respectively in 2019. The U.S. had a lower educational attainment than Finland, Iceland, Norway, and Sweden.

TABLE 1

SOCIOECONOMIC AND HEALTH CHARACTERISTICS OF THE COUNTRIES, 2019

\begin{tabular}{|l|c|c|c|c|c|c|}
\hline & USA & Denmark & Finland & Iceland & Norway & Sweden \\
\hline Population (2019) & $328 \mathrm{M}$ & $5.8 \mathrm{M}$ & $5.5 \mathrm{M}$ & $337.5 \mathrm{k}$ & $5.3 \mathrm{M}$ & $10.2 \mathrm{M}$ \\
\hline 2019 per capita GDP \$ & 53,535 & 45,244 & 40,215 & 47,062 & 63,501 & 46,388 \\
\hline 2019 fertility rate & 1.7 & 1.8 & 1.5 & 1.8 & 1.7 & 1.8 \\
\hline 2019 educational attainment (years) & 12.9 & 12.7 & 14.5 & 15.1 & 13.8 & 13.0 \\
\hline Life expectancy (observed) & \multicolumn{5}{|l|}{} \\
\hline Females (2017) & 81.1 & 82.7 & 84.3 & 85.9 & 84.2 & 84.2 \\
\hline Males (2017) & 76.1 & 78.8 & 78.5 & 79.8 & 80.5 & 80.8 \\
\hline Child mortality (observed) & \multicolumn{5}{|l|}{} \\
\hline Under 1 (2019) & 5.5 & 3.5 & 1.8 & 1.5 & 2.0 & 2.1 \\
\hline Under 5 (2019) & 6.5 & 3.0 & 2.2 & 2.2 & 2.5 & 2.6 \\
\hline Health expenditure (USD per person) & \multicolumn{7}{|l|}{} \\
\hline $\mathbf{2 0 1 8}$ & 10,271 & 6,195 & 4,656 & 6,307 & 8,269 & 6,095 \\
\hline $\mathbf{2 0 5 0}$ & 15,825 & 8,846 & 7,410 & 10,390 & 10,668 & 8,909 \\
\hline
\end{tabular}

Source: www.healthdata.org 
Although the life expectancies at birth were close to each other in the Nordic countries, the U.S. had a lower life expectancy than the Nordic countries in 2019. The economic, social, and cultural developments and improvements in the Nordic countries have significantly contributed to the increased life expectancy from birth (Ringsberg and Borup, 2011). Income inequality is not a significant problem in the Nordic countries, but there are some differences among life expectancies at birth according to their socioeconomic status. The U.S. had higher infant mortality and deaths of children under five compared to the Nordic countries.

TABLE 2

HEALTH INPUTS (2019 OR CLOSEST AVAILABLE YEAR)

\begin{tabular}{|c|c|c|c|}
\hline Health Inputs & Country Name & Year 2011 & Year 2019 \\
\hline \multirow[t]{7}{*}{ Physicians (per 1,000 people) } & USA & 2.46 & 2.61 \\
\hline & Canada & 2.10 & 2.61 \\
\hline & Denmark & 3.78 & 4.01 \\
\hline & Iceland & 3.46 & 4.08 \\
\hline & Finland & 3.12 & 3.81 \\
\hline & Norway & 2.54 & 2.92 \\
\hline & Sweden & 3.96 & 3.98 \\
\hline \multirow[t]{7}{*}{ Nurses and midwives (per 1,000 people) } & USA & 9.47 & 14.55 \\
\hline & Canada & 9.24 & 9.94 \\
\hline & Denmark & 10.14 & 10.32 \\
\hline & Iceland & 15.47 & 16.21 \\
\hline & Finland & 14.49 & 14.74 \\
\hline & Norway & 16.95 & 18.22 \\
\hline & Sweden & 11.76 & 11.82 \\
\hline \multirow[t]{7}{*}{ Hospital beds (per 1,000 people) } & USA & 2.97 & 2.87 \\
\hline & Canada & 2.80 & 2.52 \\
\hline & Denmark & 3.13 & 2.60 \\
\hline & Iceland & 3.29 & 2.83 \\
\hline & Finland & 5.52 & 3.61 \\
\hline & Norway & 4.19 & 3.53 \\
\hline & Sweden & 2.70 & 2.14 \\
\hline
\end{tabular}

Source: World Development Indicators, https://databank.worldbank.org/

Table 2 shows the health inputs of the U.S. and Nordic countries in terms of physicians per 1,000 people, nurses and midwives per 1,000 people, and hospital beds per 1,000 people. The availability of healthcare inputs can affect a health system's functioning in various ways, including access to health services, cost of care, and disaster preparedness. The U.S. has more acute care hospital beds per capita than Denmark, Finland, and Norway. Although the U.S. had fewer doctors per capita than the Nordic countries, it had more nurses per capita than Denmark and Sweden in 2019 (World Development Indicators, 2021).

The U.S. and Nordic countries showed differences in burden of diseases, a measurement that considers both longevity and quality of life. Table 3 shows that the burden of disease and health-threatening risk factors of the Nordic countries are similar. Ischemic heart disease is seen as the number one cause for most deaths in both health systems. Alzheimer's disease, stroke, lung cancer, and COPD are among the top five conditions that cause the most deaths in the U.S. and Nordic countries. The respective countries' economic development levels and longer life expectancies contribute to the similarity. The U.S. had more deaths and 
cases of coronavirus in 2020, and the burden of disease and health spending in the coming years is expected to increase due to the pandemic. Because of geography and climate, falls were among the top ten causes of death in Canada, Finland, and Norway.

TABLE 3

TOP 10 CAUSES OF DEATH IN THE U.S. AND THE NORDIC COUNTRIES IN 2019, ALL AGES

\begin{tabular}{|c|c|c|c|c|c|c|}
\hline USA & Canada & Denmark & Finland & Iceland & Norway & Sweden \\
\hline $\begin{array}{l}\text { Ischemic } \\
\text { heart } \\
\text { disease }\end{array}$ & $\begin{array}{l}\text { Ischemic } \\
\text { heart } \\
\text { disease }\end{array}$ & $\begin{array}{l}\text { Ischemic } \\
\text { heart } \\
\text { disease }\end{array}$ & $\begin{array}{l}\text { Ischemic } \\
\text { heart disease }\end{array}$ & $\begin{array}{l}\text { Ischemic } \\
\text { heart } \\
\text { disease }\end{array}$ & $\begin{array}{l}\text { Ischemic } \\
\text { heart } \\
\text { disease }\end{array}$ & $\begin{array}{l}\text { Ischemic } \\
\text { heart } \\
\text { disease }\end{array}$ \\
\hline Lung cancer & Lung cancer & $\begin{array}{l}\text { Alzheimer's } \\
\text { disease }\end{array}$ & Stroke & Lung cancer & Stroke & $\begin{array}{l}\text { Alzheimer's } \\
\text { disease }\end{array}$ \\
\hline COPD & Stroke & Lung cancer & $\begin{array}{l}\text { Alzheimer's } \\
\text { disease }\end{array}$ & $\begin{array}{l}\text { Alzheimer's } \\
\text { disease }\end{array}$ & $\begin{array}{l}\text { Alzheimer's } \\
\text { disease }\end{array}$ & Stroke \\
\hline Stroke & $\begin{array}{l}\text { Alzheimer's } \\
\text { disease }\end{array}$ & Stroke & Lung cancer & Stroke & COPD & Lung cancer \\
\hline $\begin{array}{l}\text { Alzheimer's } \\
\text { disease }\end{array}$ & COPD & COPD & $\begin{array}{l}\text { Colorectal } \\
\text { cancer }\end{array}$ & Self-harm & Lung cancer & COPD \\
\hline $\begin{array}{l}\text { Chronic } \\
\text { kidney } \\
\text { disease }\end{array}$ & $\begin{array}{l}\text { Colorectal } \\
\text { cancer }\end{array}$ & $\begin{array}{l}\text { Lower } \\
\text { respiratory } \\
\text { infections }\end{array}$ & COPD & COPD & $\begin{array}{l}\text { Lower } \\
\text { respiratory } \\
\text { infections }\end{array}$ & $\begin{array}{l}\text { Colorectal } \\
\text { cancer }\end{array}$ \\
\hline $\begin{array}{l}\text { Colorectal } \\
\text { cancer }\end{array}$ & $\begin{array}{l}\text { Lower } \\
\text { respiratory } \\
\text { infect }\end{array}$ & $\begin{array}{l}\text { Colorectal } \\
\text { cancer }\end{array}$ & $\begin{array}{l}\text { Hypertensive } \\
\text { heart disease }\end{array}$ & $\begin{array}{l}\text { Colorectal } \\
\text { cancer }\end{array}$ & $\begin{array}{l}\text { Colorectal } \\
\text { cancer }\end{array}$ & $\begin{array}{l}\text { Lower } \\
\text { respiratory } \\
\text { infections }\end{array}$ \\
\hline $\begin{array}{l}\text { Lower } \\
\text { respiratory } \\
\text { infections }\end{array}$ & $\begin{array}{l}\text { Chronic } \\
\text { kidney } \\
\text { disease }\end{array}$ & $\begin{array}{l}\text { Prostate } \\
\text { cancer }\end{array}$ & Falls & $\begin{array}{l}\text { Lower } \\
\text { respiratory } \\
\text { infections }\end{array}$ & $\begin{array}{l}\text { Prostate } \\
\text { cancer }\end{array}$ & $\begin{array}{l}\text { Atrial } \\
\text { fibrillation }\end{array}$ \\
\hline Diabetes & Diabetes & $\begin{array}{l}\text { Breast } \\
\text { cancer }\end{array}$ & $\begin{array}{l}\text { Pancreatic } \\
\text { cancer }\end{array}$ & $\begin{array}{l}\text { Pancreatic } \\
\text { cancer }\end{array}$ & Falls & $\begin{array}{l}\text { Prostate } \\
\text { cancer }\end{array}$ \\
\hline Cirrhosis & Falls & Diabetes & $\begin{array}{l}\text { Prostate } \\
\text { cancer }\end{array}$ & $\begin{array}{l}\text { Prostate } \\
\text { cancer }\end{array}$ & $\begin{array}{l}\text { Pancreatic } \\
\text { cancer }\end{array}$ & $\begin{array}{l}\text { Breast } \\
\text { cancer }\end{array}$ \\
\hline
\end{tabular}

Sources: 1- Murray, C.J.L., Aravkin, A.Y., Zheng, P., Abbafati, C., Abbas, K.M., Abbasi-Kangevari, M., ... \& Lim, S.S. (2020). Global burden of 87 risk factors in 204 countries and territories, 1990-2019: a systematic analysis for the Global Burden of Disease Study 2019. Lancet (London, England), 396(10258), 1223-49.

2-www.healthdata.org

Table 4 shows the top 10 risks contributing to death and disability defined as disability-adjusted life years (DALYs), which is the sum of years of potential life lost due to premature mortality and the years of productive life lost due to disability. Cardiovascular diseases and cancers are at the forefront of the disease burden rankings in both the U.S. and Nordic countries. For this reason, it is essential to focus on what causes these diseases. Attempts to reduce tobacco and alcohol use will significantly reduce these diseases' incidence (see Table 4). Table 4 shows that the U.S. and Nordic countries face significant dietary risks. Both government and industry should focus on healthy life choices intheir countries (Knudsen et al., 2019). The U.S. and Nordic countries' administrations should create programs for proper nutrition. These programs could include access to nutritious foods, labeling of food products, and tax incentives.

In both health systems, high body-mass index, high fasting plasma glucose, high blood pressure, and high LDL were other factors leading to death and disability (Murray et al., 2020). These risk factors were related to the people's dietary habits and physical activity in both health systems. Tobacco and alcohol use are among the top five risk factors. The statistics show that smoking and alcohol use cause chronic ailments 
and deaths in both health systems (Knudsen et al., 2019). The non-optimal temperature, an aggregate of the burden attributable to low and high temperatures, was reported as a risk among Denmark's and Sweden's top 10 risk factors. Occupational risks had been reported as top risk factors by all countries. These risk factors include occupational injuries, ergonomic factors, and exposure to particulate matter, fumes and gases, carcinogens, noise, and asthmagens (Murray et al., 2020).

\section{TABLE 4 \\ TOP 10 RISKS CONTRIBUTING TO DEATH AND DISABILITY COMBINED (DISABILITY ADJUSTED LIFE YEARS (DALYS) IN THE U.S. AND THE NORDIC COUNTRIES IN 2019, ALL AGES}

\begin{tabular}{|c|c|c|c|c|c|c|}
\hline USA & Canada & Denmark & Finland & Iceland & Norway & Sweden \\
\hline Tobacco & Tobacco & Tobacco & $\begin{array}{l}\text { High blood } \\
\text { pressure }\end{array}$ & Tobacco & Tobacco & Tobacco \\
\hline $\begin{array}{l}\text { High body- } \\
\text { mass index }\end{array}$ & $\begin{array}{l}\text { High body- } \\
\text { mass index }\end{array}$ & $\begin{array}{l}\text { High blood } \\
\text { pressure }\end{array}$ & Tobacco & $\begin{array}{l}\text { High body- } \\
\text { mass index }\end{array}$ & $\begin{array}{l}\text { High blood } \\
\text { pressure }\end{array}$ & $\begin{array}{l}\text { High blood } \\
\text { pressure }\end{array}$ \\
\hline $\begin{array}{l}\text { High fasting } \\
\text { plasma } \\
\text { glucose }\end{array}$ & $\begin{array}{l}\text { High blood } \\
\text { pressure }\end{array}$ & Alcohol use & $\begin{array}{l}\text { High fasting } \\
\text { plasma } \\
\text { glucose }\end{array}$ & $\begin{array}{l}\text { High blood } \\
\text { pressure }\end{array}$ & $\begin{array}{l}\text { High fasting } \\
\text { plasma } \\
\text { glucose }\end{array}$ & Dietary risks \\
\hline $\begin{array}{l}\text { High blood } \\
\text { pressure }\end{array}$ & $\begin{array}{l}\text { High fasting } \\
\text { plasma } \\
\text { glucose }\end{array}$ & Dietary risks & Dietary risks & Dietary risk & Dietary risks & $\begin{array}{l}\text { High fasting } \\
\text { plasma } \\
\text { glucose }\end{array}$ \\
\hline Dietary risks & Dietary risks & $\begin{array}{l}\text { High fasting } \\
\text { plasma } \\
\text { glucose }\end{array}$ & $\begin{array}{l}\text { High body- } \\
\text { mass index }\end{array}$ & $\begin{array}{l}\text { High fasting } \\
\text { plasma } \\
\text { glucose }\end{array}$ & $\begin{array}{l}\text { High body- } \\
\text { mass index }\end{array}$ & $\begin{array}{l}\text { High body- } \\
\text { mass index }\end{array}$ \\
\hline Drug use & Alcohol use & $\begin{array}{l}\text { High body- } \\
\text { mass index }\end{array}$ & Alcohol use & High LDL & High LDL & Alcohol use \\
\hline Alcohol use & $\begin{array}{l}\text { Occupationa } \\
1 \text { risks }\end{array}$ & $\begin{array}{l}\text { Occupationa } \\
1 \text { risks }\end{array}$ & High LDL & Alcohol use & Alcohol use & High LDL \\
\hline High LDL & High LDL & High LDL & $\begin{array}{l}\text { Occupationa } \\
1 \text { risks }\end{array}$ & $\begin{array}{l}\text { Occupationa } \\
1 \text { risks }\end{array}$ & $\begin{array}{l}\text { Occupationa } \\
1 \text { risks }\end{array}$ & $\begin{array}{l}\text { Occupationa } \\
1 \text { risks }\end{array}$ \\
\hline $\begin{array}{l}\text { Kidney } \\
\text { dysfunction }\end{array}$ & Drug use & $\begin{array}{l}\text { Kidney } \\
\text { dysfunction }\end{array}$ & $\begin{array}{l}\text { Kidney } \\
\text { dysfunction }\end{array}$ & Drug use & Drug use & $\begin{array}{l}\text { Kidney } \\
\text { dysfunction }\end{array}$ \\
\hline $\begin{array}{l}\text { Occupationa } \\
1 \text { risks }\end{array}$ & $\begin{array}{l}\text { Kidney } \\
\text { dysfunction }\end{array}$ & $\begin{array}{l}\text { Non- } \\
\text { optimal } \\
\text { temperature }\end{array}$ & Drug use & $\begin{array}{l}\text { Kidney } \\
\text { dysfunction }\end{array}$ & $\begin{array}{l}\text { Kidney } \\
\text { dysfunction }\end{array}$ & $\begin{array}{l}\text { Non- } \\
\text { optimal } \\
\text { temperature }\end{array}$ \\
\hline
\end{tabular}

Sources: 1- Murray, C.J.L., Aravkin, A.Y., Zheng, P., Abbafati, C., Abbas, K.M., Abbasi-Kangevari, M., ... \& Lim, S.S. (2020). Global burden of 87 risk factors in 204 countries and territories, 1990-2019: a systematic analysis for the Global Burden of Disease Study 2019. Lancet (London, England), 396(10258), 1223-49.

2-www.healthdata.org

Table 5 shows the health expenditures in 2020, 2030, and 2050 in both the U.S. and the Nordic countries. The U.S. and the Nordic countries spend considerably more on health care than many developing countries, while the U.S. spends more on healthcare than the Nordic countries. In the U.S., per capita health spending was $\$ 11,267$ in 2020, a number that is expected to rise to $\$ 12,734$ in 2030 and $\$ 17,233$ in 2050 . Norway had the highest per capita health spending among the Nordic countries, estimated to be $\$ 8,306$ in 2020; this expenditure will grow to $\$ 9,148$ in 2030 and $\$ 10,624$ in 2050. Other Nordic countries' per capita health spending appear to be close to each other (Micah et al., 2020). 


\section{DISCUSSION}

Statistics show that the Nordic countries have better healthcare than the U.S. for less money. There are many reasons for these differences. First, Nordic countries have a unique set of policies and procedures for arranging doctors and specialists, as well as distribution of hospitals and clinics (Magnussen et al., 2009). Second, the economic case for a single-payer health insurer is strong; private insurance is an expensive way to fund health care in Nordic countries (Rushton, 2009). Third, Nordic countries have strong primary care and referral systems where people can easily access essential health services without any barrier. In the U.S., the primary care system is extremely pluralistic, and service costs more than in Nordic countries (Berwick et al., 2008). Fourth, financing and control of the health system is decentralized to the county or community level (Magnussen et al., 2009; Scheele et al., 2017). Fifth, physicians and other health professionals are not highly paid in the Nordic countries (Rushton, 2009). Sixth, the Nordic people's health literacy levels are high, and their physical culture is better than in the U.S. (Kokko et al., 2018). Seventh, the Nordic governments have strong health promotion and education policies and higher taxes on tobacco, sugar, etc. (Ringsberg and Borup, 2011). Finally, the U.S. political system has a two-party system, which is perceived to create a 'winner take all' mentality (Page, 2016). The Nordic multiparty system leads to coalitions and consensus.

TABLE 5

HEALTH EXPENDITURES (2019 U.S. PURCHASING-POWER PARITY-ADJUSTEDDOLLARS PER CAPITA)

\begin{tabular}{|c|c|c|c|c|c|}
\hline & Year & $\begin{array}{c}\text { Total health } \\
\text { spending }\end{array}$ & $\begin{array}{c}\text { Government } \\
\text { health } \\
\text { spending } \\
\end{array}$ & $\begin{array}{c}\text { Out-of-pocket } \\
\text { health } \\
\text { spending }\end{array}$ & $\begin{array}{c}\text { Prepaid } \\
\text { private health } \\
\text { spending }\end{array}$ \\
\hline \multirow[t]{3}{*}{ USA } & 2020 & 11267 & 5968 & 1246 & 4053 \\
\hline & 2030 & 12734 & 7095 & 1235 & 4405 \\
\hline & 2050 & 17233 & 9688 & 1455 & 6091 \\
\hline \multirow[t]{3}{*}{ Canada } & 2020 & 5683 & 4212 & 788 & 683 \\
\hline & 2030 & 6159 & 4642 & 784 & 72 \\
\hline & 2050 & 7301 & 5534 & 878 & 89 \\
\hline \multirow[t]{3}{*}{ Denmark } & 2020 & 5656 & 4770 & 761 & 126 \\
\hline & 2030 & 5911 & 5018 & 760 & 133 \\
\hline & 2050 & 6815 & 5837 & 820 & 158 \\
\hline \multirow[t]{3}{*}{ Finland } & 2020 & 4450 & 3410 & 906 & 134 \\
\hline & 2030 & 4796 & 3722 & 929 & 146 \\
\hline & 2050 & 6192 & 4952 & 1048 & 192 \\
\hline \multirow[t]{3}{*}{ Iceland } & 2020 & 4638 & 3780 & 778 & 79 \\
\hline & 2030 & 4780 & 3908 & 790 & 82 \\
\hline & 2050 & 5653 & 4666 & 888 & 100 \\
\hline \multirow[t]{3}{*}{ Norway } & 2020 & 8306 & 7107 & 1170 & 30 \\
\hline & 2030 & 9148 & 7960 & 1156 & 32 \\
\hline & 2050 & 10624 & 9459 & 1127 & 38 \\
\hline \multirow[t]{3}{*}{ Sweden } & 2020 & 6268 & 5283 & 906 & 80 \\
\hline & 2030 & 7455 & 6412 & 950 & 94 \\
\hline & 2050 & 9633 & 8422 & 1088 & 123 \\
\hline
\end{tabular}

Source: Micah, A.E., Su, Y., Bachmeier, S.D., Chapin, A., Cogswell, I.E., Crosby, S.W., ... \& Dieleman, J.L. (2020). Health sector spending and spending on HIV/AIDS, tuberculosis, and malaria, and development assistance for health: progress towards Sustainable Development Goal 3. Lancet (London, England), 396(10252), 693-724. 


\section{CONCLUSION}

As in all developed countries, the U.S. and Nordic countries' health systems face similar disease burdens and health outcomes, but their solutions vary due to the difference in health financing and different geography. This research shows the difficulty of reaching Nordic countries' level in terms of health outcomes, despite the U.S.'s higher per capita health spending. The Nordic system has lower health costs, more health services, universal access to health care without any financial barriers, and superior health status. The Nordic countries also have longer life expectancies and lower child mortality rates than Americans. There are many lessons that the U.S. and Nordic countries can learn from each other.

\section{REFERENCES}

Bauer, U.E., Briss, P.A., Goodman, R.A., \& Bowman, B.A. (2014). Prevention of chronic disease in the 21 st century: Elimination of the leading preventable causes of premature death and disability in the USA. The Lancet, 384(9937), 45-52. https://doi.org/10.1016/s0140-6736(14)60648-6

Berwick, D.M., Nolan, T.W., \& Whittington, J. (2008). The Triple Aim: Care, health, and cost. Health Affairs, 27(3), 759-769. https://doi.org/10.1377/hlthaff.27.3.759

CMS. Medicare enrollment dashboard. (2021, January 22). Retrieved from https://www.cms.gov/Research-Statistics-Data-and-Systems/Statistics-Trends-andReports/CMSProgramStatistics/Dashboard

GBD results tool. (n.d.). Retrieved from https://ghdx.healthdata.org/gbd-results-tool

Knudsen, A.K., Allebeck, P., Tollånes, M.C., Skogen, J.C., Iburg, K.M., McGrath, J.J., ... Øverland, S., (2019, December). Life expectancy and disease burden in the Nordic countries: results from the Global Burden of Diseases, Injuries, and Risk Factors Study 2017. Lancet Public Health, (12), e658-e669. doi: 10.1016/S2468-2667(19)30224-5

Kokko, S., Liveng, A., \& Torp, S. (2018). 20 years of health promotion research in the Nordic countries: Health, wellbeing and physical activity. Scandinavian Journal of Public Health, 46(20_suppl), 36. https://doi.org/10.1177/1403494817751041

Luft, H.S. (2006). What works and what doesn't work well in the US healthcare system. PharmacoEconomics, 24(S2), 15-28. https://doi.org/10.2165/00019053-200624002-00003

Magnussen J, Vrangbæk K, Salman RB. (2009). Nordic health care systems: recent reforms and current policy challenges. Open University Press.

Micah, A.E., Su, Y., Bachmeier, S.D., Chapin, A., Cogswell, I.E., Crosby, S.W., ... Dieleman, J.L. (2020). Health sector spending and spending on HIV/AIDS, tuberculosis, and malaria, and development assistance for health: Progress towards Sustainable Development Goal 3. Lancet (London, England), 396(10252), 693-724.

Murray, C.J.L., Aravkin, A.Y., Zheng, P., Abbafati, C., Abbas, K.M., Abbasi-Kangevari, M., ... \& Lim, S.S. (2020). Global burden of 87 risk factors in 204 countries and territories, 1990-2019: A systematic analysis for the Global Burden of Disease Study 2019. Lancet (London, England), 396(10258), 1223-49.

Page, L. (2016). What Donald Trump would do with the US healthcare system. BMJ, i2996. https://doi.org/10.1136/bmj.i2996

Ringsberg, K.C., \& Borup, I. (2011). The role of health promotion in the transition of the Nordic welfare states. Scandinavian Journal of Public Health, 39(6_suppl), 4-5. https://doi.org/10.1177/1403494810395841

Rowland, D., \& Garfield, R. (2000). Health Care for the Poor: Medicaid at 35. Health Care Financing Review, 22(1), 23-34.

Rushton, F.E. (2009). US health-care crisis. Pediatrics International, 51(5), 603-605. https://doi.org/10.1111/j.1442-200x.2009.02920.x

Scheele, C. E., Little, I., \& Diderichsen, F. (2017). Governing health equity in Scandinavian municipalities: The inter-sectorial challenge. Scandinavian Journal of Public Health, 46(1), 57- 
67. https://doi.org/10.1177/1403494816685538

Shi, \& Singh, D.A. (2015). Essentials of the U.S. health care system. Jones \& Bartlett Publishers.

Turner, G. (2002). A profile of the health sector in the United States. PharmacoEconomics, 20(Supplement 3), 31-45. https://doi.org/10.2165/00019053-200220003-00003

World development indicators. (n.d.). Retrieved from https://databank.worldbank.org/source/worlddevelopment-indicators 